(RESEARCH ARTICLE)

\title{
Chemical analysis and nutritional study of shrimp powder (Penaeus notialis, Peneids, Decapods) from Côte d'Ivoire freshwater in rats (Rattus novegeus, Wistar).
}

\author{
Dally Theodor 1, ${ }^{*}$, Diby Yao Bernard 2, Kahoubi Gohi Parfait 2, Kouamé Bruno 3, Ouattara Howele 4, Méité \\ Alassane ${ }^{3}$ and Kati-Coulibaly Séraphin ${ }^{3}$.
}

\begin{abstract}
${ }^{1}$ Education team in animal physiology, Training and Research Unit (UFR) Environment, Jean Lorougnon Guédé University; Daloa Côte d'Ivoire.

${ }^{2}$ Education team in animal physiology, Training and Research Unit (UFR) Agroforestry, Jean Lorougnon Guédé University; Daloa Côte d'Ivoire.

${ }^{3}$ Nutrition and Pharmacology Laboratory, Biosciences Training and Research Unit (UFR), Félix Houphouët Boigny University, Abidjan, Côte d'Ivoire.

Department of animal physiology, Department of Biological Sciences, Pelefero Gon Coulibaly University, Korhogo Côte d'Ivoire.
\end{abstract}

Publication history: Received on 17 February 2020; revised on 06 March 2020; accepted on 19 March 2020

Article DOI: https://doi.org/10.30574/wjarr.2020.6.1.0046

\begin{abstract}
Shortage and high cost of conventional proteins (meat and fish) in our developing countries means that we have to find new sources of protein. The shrimp (Penaeus notialis), produced in large quantities worldwide and particularly in Côte d'Ivoire, is a track to be exploited. This study was conducted to assess the nutritional quality of this unconventional protein from freshwater. Overall chemical characterization in grams per $100 \mathrm{~g} / \mathrm{dry}$ matter of the powder of this animal was carried out by standard methods (AOAC). The macromolecule content (carbohydrate, fat and protein) gave 44.4\%, $7.86 \%$ and $34.21 \%$ respectively. Nutritional parameters that are the total dry matter ingested (MSTI), the total protein ingested (PTI) in grams/ day and the food efficiency coefficient (CEA), the protein efficiency coefficient (CEP) and the weight of these animals were evaluated on the basis of animal experimentation carried out in the animal physiology laboratory. Second consumption experiment gave an MSTI of $8.8 \mathrm{~g} /$ day respectively with a PTI of 0.82 on the one hand. On the other hand, a CEA of 0.20 and a CEP of 1.91 for the shrimp diet.All these values show no significant difference with that of the control diet (Casein) and the fish diet. The growth determined by the weight variation of rats fed the shrimp diet remains greater compared to that of the control and fish diets.This study showed that proteins from the shrimp diet (Penaeus notialis) may well be a nutritional alternative alongside conventional meat. Additional studies may be conducted to more specifically determine the micronutrient composition of this animal protein.
\end{abstract}

Keywords: Protein efficiency; Côte d'Ivoire; Nutritional quality; Proteins; Shrimp (Penaeus notialis)

\section{Introduction}

Protein-energy malnutrition places functional nutrition disorders at the forefront[1] (FA0, 2012); [2] (IFPRI, 2016).This remains a serious challenge for food security[3] Svanberg et al, (1997).Malnutrition in all its forms (under nutrition, micronutrient deficiency, overweight and obesity) still plagues all over the world and more particularly in developing countries such as the Ivory Coast country of Africa. 'Where is malnutrition, whatever form it reveals, results from a poor diet or eating habit, from a nutrient deficiency, from a lack of knowledge of our available resources. These are all factors that have underlying causes [4] Shetty and Phersonn (1997); [5]Aristya et al, (2008); [6] Satmala et al,(2017). Malnutrition is a real obstacle to the sustainable development of our developing countries, whether it is to guarantee food security and maintain satisfactory nutrition [7] (WHO, 2010).

\footnotetext{
${ }^{*}$ Corresponding author: Dally Theodor
} 
; In addition, the exponential growth of the world population and that of the developing countries entail an increasingly high demand for foodstuffs rich in proteins. Access to different sources of traditional animal protein (meat and fish is becoming increasingly difficult and expensive. In view of this situation, it is imperative to find new sources of unconventional animal proteins which may constitute an interesting alternative. With a total production of 13,720 tonnes in 2016. Shrimp (Penaeus notialis) from the Pénaeideae family could replace the various conventional resources [8](FA0, 2003).

This animal species in Ivory Coast has several vernacular names. These are, among others, "Gagagbo" (Bété), "N'zécrézé" (Baoulé), "Zonzon" (Malinké), "Séé" (Gouro), "Gnagalo "(Dida)," Alé "(Akyé).This animal has a high nutritional value with a pulpit of exceptional good quality ([9]Hinard, (1984);[10]AOAC, (1980). This is generally used in making seasoning cubes. Unfortunately, few studies have been done on the nutritional properties of the proteins in its freshwater crustaceans. A valuation study of the nutritional quality of the protein of this animal species was initiated with a view to popularizing the consumption of this animal encountered on our different markets in Cote d'Ivoire.

\section{Material and methods}

\subsection{Animal material}

The dried prawns (Penaeus notialis), once purchased (Locodjro Abidjan market) were then sorted and disposed of all kinds of waste.

They were crushed using a kitchen mortar to obtain the dried shrimp powder and stored in clean jars in the freezer at $5^{\circ} \mathrm{C}$.

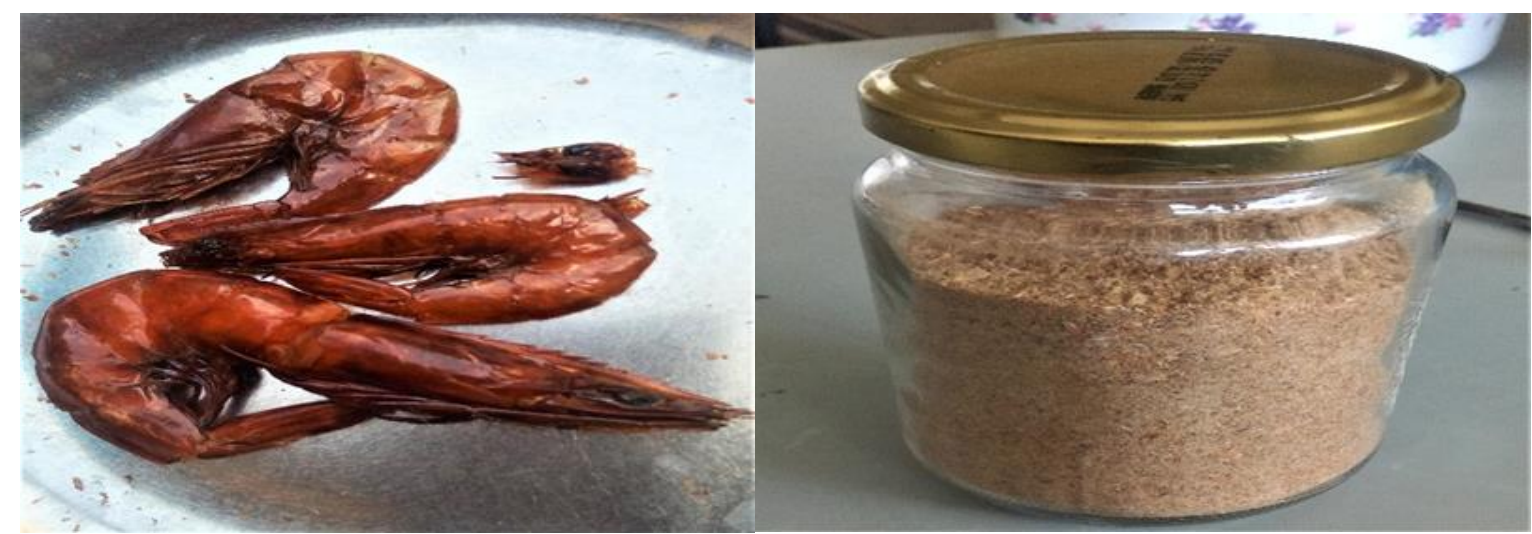

Figure 1 Shrimp and shrimp powder stored in a jar

\subsection{Analyse chimique}

Chemical analysis of food : the moisture content was ditermed by drying the fresh dish in an oven at $105^{\circ} \mathrm{C}$ until constant weight, ash by incineration in a murflefunace at $505^{\circ} \mathrm{C}$ for $48 \mathrm{~h}$, properties by nitrogen determination using the kjeldahl method and conversion of nitrogen to proteins by the 6,25, total lipids by extraction in a Soxhlet apparatus for $6 \mathrm{~h}$ using petroleum ether as solvent fibers by successive digestion of the defattaded stample with $0,26 \mathrm{~N}$, sulfuric acid and $0,23 \mathrm{~N}$ potassium hydroxyd solution and carbohydrates by difference method [11]AOAC, (1998);[12 ]Abu and Eli, (2018).

\subsection{Animal testing}

The diets were distributed ad libitum once a day at 7 a.m. in the form of mash, to avoid wastage. Ingests were determined by weighing the feeders when they were put in and when they were removed. The quantities of fresh food consumed were obtained by the difference between the quantities distributed and the quantities remaining or refused. The water was served ad libitum and renewed every three days. The animals were weighed at the start of the experiment and then at three-day intervals. The last weighing took place at the end of the experiment. Growth was determined by the difference between the initial weight and the final weight. 


\subsection{Food and growth record}

\subsubsection{Experimental protocol}

Diets were distributed ad libitum once a day at 7 a.m. in the form of mash, to avoid wastage. Ingests were determined by weighing the feeders when they were put in and when they were removed.

Quantities of fresh food consumed were obtained by the difference between the quantities distributed and the quantities remaining or refused. The water was served ad libitum and renewed every three days. The animals were weighed at the start of the experiment and then at three-day intervals. The last weighing took place at the end of the experiment. Growth was determined by the difference between the initial weight and the final weight.

\subsubsection{Determination of consumption parameters, growth and food efficiency}

The quantities of food ingested are converted into dry matter ingested. The percentage of protein in the food was evaluated based on the amount of food ingested.

It is expressed in grams (g) or grams per day (g/d). These quantities have been converted into ingested dry matter.

\subsubsection{Total Dry Ingested Matter (MSTI) g/days}

The amount of Total Ingested Dry Matter (MSTI) represents the total amount of food ingested as dry matter by the animal during the duration of the experiment.

MSTI (g/days) = sum of the quantities of dry matter (food) ingested during the experimental period over number of days of consumption.

\subsubsection{Total Ingested Protein (ITP) g/days}

Total Ingested Protein (PTI) represents the amount of dietary protein ingested during the duration of the experiment.

PIT (g/days) = MSTI x percentage of protein in the diet / number of days.

\subsubsection{Food growth and efficiency}

The growth, translated by the weight gain (GP), is obtained by the difference between the final weight and the initial weight it is expressed in $\mathrm{g} / \mathrm{d}$ [13](Adrian et al, 1991).

GP (g/days) $=$ Final weight - initial weight $/$ number of days.

\subsubsection{Food efficiency measure}

Food efficiency coefficient (CEA)

It reflects the yield with which the food is assimilated. In other words, it is the weight gain favored by the ingestion of $1 \mathrm{~g}$ of food.The CEA was calculated by relating the weight gain ( $\mathrm{g} /$ days) to the amount of MSTI (g/days).

$$
C E A=\frac{\text { Weight gain }}{\text { Total dry ingested matter }}
$$

Uncorrected protein efficiency coefficient (CEP)

The CEP was obtained by relating the weight gain (g / d) to the ITP (g / d).

It reflects the efficiency of using the diet food.

$$
C E P=\frac{\text { Weight gain }(g)}{\text { Total ingested protein }(g)}
$$




\subsection{Statistical analysis}

Data were expressed as mean \pm standard deviation. The data analysis was carried out by Anova using STATISTICA software (7.1). Comparison was made from the descriptive analysis test of the data collected, was made from the Newman Keuls test at the 5\% threshold. The present graphics were made using GraphPadPrism 7.00 software.

\section{Results and discussion}

Table 10verall chemical composition of shrimp powder

\begin{tabular}{ll}
\hline Paramters & Contents \\
\hline Humidity (g/100g MF) & 9,66 \\
Dry matter (g/100g MS) & 90,30 \\
carbohydrate(g/100g MS) & 44,40 \\
lipids(g/100g MS) & 7,86 \\
Proteins(g/100g MS) & 34,21 \\
Ash (g/100g MS) & 13,53 \\
\hline \multicolumn{2}{c}{ Each value is the mean \pm SEM of six rats. }
\end{tabular}

Table 2MSTI; PTI, CEA and CEP of rats subjected to different diets

\begin{tabular}{llll}
\hline DIETS & & & \\
\hline & RTC & RFP & RTCr \\
& $\mathbf{n = 6}$ & $\mathbf{n = 6}$ & $\mathbf{n = 6}$ \\
\cline { 2 - 4 } MSTI(g/days) & $8,49 \pm 0,02 \mathrm{a}$ & $9,32 \pm 0,02 \mathrm{a}$ & $8,81 \pm 0,12 \mathrm{a}$ \\
PTI(g/days) & $0,84 \pm 0,00 \mathrm{a}$ & $0,93 \pm 0,00 \mathrm{a}$ & $0,82 \pm 0,01 \mathrm{a}$ \\
CEA & $0,09 \pm 0,02 \mathrm{a}$ & $0,16 \pm 0,02 \mathrm{a}$ & $0,20 \pm 0,03 \mathrm{a}$ \\
CEP & $0,96 \pm 0,01 \mathrm{a}$ & $1,60 \pm 0,02 \mathrm{a}$ & $1,71 \pm 0,03 \mathrm{a}$ \\
\hline
\end{tabular}

Each value is the mean \pm SEM of six rats

A, there is no significant in the table when designer by the same letter.

RTC: control diet (casein); RFP: diet of fich; RTCr; diet of shrimp powder

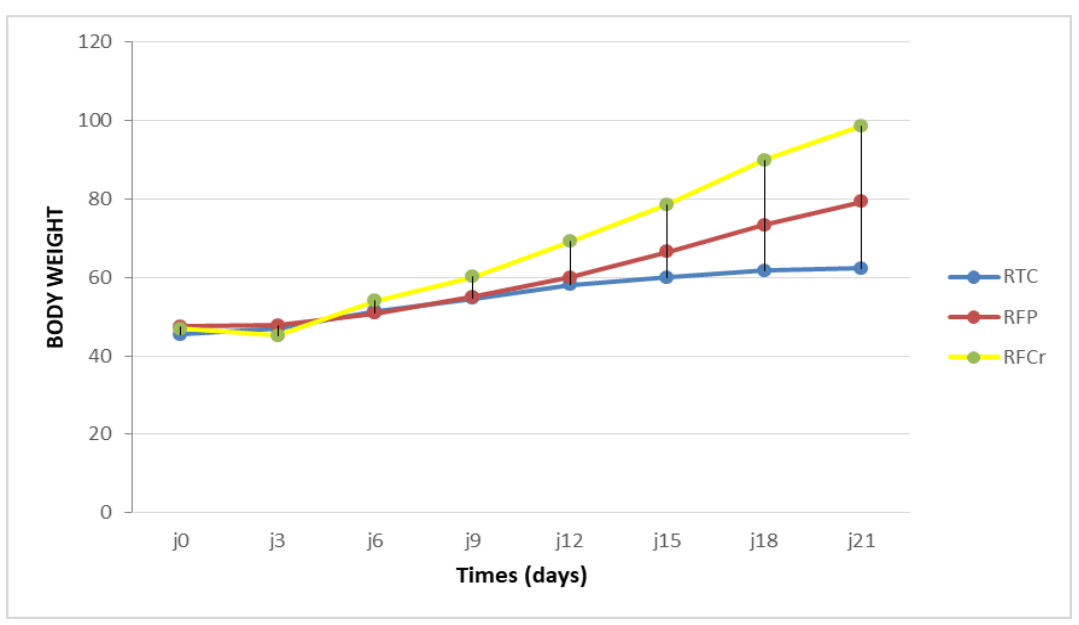

Figure 2 Growth curves of young rats fed the RTC, RFP and RFCr diets 


\section{Discussion}

Dried shrimp powder is rich in essential nutrients that can contribute to the proper functioning of the body. This flour has a moisture content which is $9.66 \mathrm{~g} / 100 \mathrm{gFM}$. It is slightly lower than that found by [14] Edah and Adeyemi (2016): on the smoked Penaeus notialis shrimp which is $14.90 \mathrm{~g} / 100 \mathrm{gFM}$.This low content is due to the very pronounced drying of the shrimp. Indeed, this low water content of this food guarantees good preservation. Proteins represent $34.21 \mathrm{~g} /$ $100 \mathrm{~g} \mathrm{DM}$, this protein content of the dried shrimp powder is lower than that found by [14] Edah and Adeyemi (2016):on the smoked Penaeus notiali sshrimp which is $51.17 \mathrm{~g} / 100 \mathrm{~g}$ DM and also to that of smoked oyster which is $56.41 \mathrm{~g} / 100 \mathrm{~g}$ DM.This difference in protein can be explained by the fact that the shrimp purchased already dried underwent further drying which must have influenced this result. It is still higher than that found by [15]Salvini et al,(1998). On the fresh Penaeus notialis shrimp which is $6.09 \mathrm{~g} / 100 \mathrm{gMS}$ and also higher than that of rabbit meat, chicken, veal and pork which are respectively $23.7 \mathrm{~g} /$ 100gMS, $22.2 \mathrm{~g} / 100 \mathrm{gMS}, 20.7 \mathrm{~g} / 100 \mathrm{~g}$ DM and $19.9 \mathrm{~g} / 100 \mathrm{gMS}$ [16]FA0, 2003).However, these protein levels are higher than the official recommendations of [17]OMS, (1985)which indicates that the required protein level for a balanced meal is between 12 and $15 \%$.

The essential function of a food protein is to meet the body's needs for nitrogen and essential amino acids [18] Azibuo et al, (2008):as for the fat (lipids) obtained, they are $7.86 \mathrm{~g} / 100 \mathrm{gMS}$. This value remains lower than that of Penaeus notialis smoked in the work of [14] Edah and Adeyemi, (2016): which is $10.13 \mathrm{~g} / 100 \mathrm{gDM}$ as well as those of rabbit, chicken and pork which are respectively $14.4 \mathrm{~g} / 100 \mathrm{gDM}, 12.4 \mathrm{~g} / 100 \mathrm{gDM}$ and $22.1 \mathrm{~g} / 100 \mathrm{~g}$ DM. However, it remains identical to that of veal which is $7 \mathrm{~g} / 100 \mathrm{~g}$ DM and higher than that of the oyster $5.32 \mathrm{~g} / 100 \mathrm{~g}$ DM. The factors for variation in lipid content in an animal are manifold and include age, sex, genotype, diet and breeding conditions. External, inter and intramuscular lipid deposits increase with the age of the animal. The lipids contained in shrimp contain, in fact, a majority of monounsaturated and polyunsaturated fatty acids whose protective effects on health are widely recognized.

Lipids, especially polyunsaturated fatty acids, are beneficial in controlling cholesterolemia and protecting against cardiovascular disease [19] Zannou, (2005).Physiological and nutritional studies were carried out on young rats growing with the casein (RTC), fish (RFP) and shrimp (RTCr) diets. The purpose of this study was to show the effectiveness or not of the shrimp diet in view of the analytical study previously carried out and which made it possible to determine some of their nutritional chemical characteristics. However, after six (6) days of consumption of the different diets (RTC, RFP and RTCr), the average weights of the rats (50-53 g) show no significant difference between the rats consuming the three diets $\mathrm{p} \geq 0,05$.

This period could be compared to the adaptation phase to these different formulated regimes. From the 6th day until the end of the experiment (21st day), a much higher weight gain is observed in the rat fed the shrimp diet with $98.73 \mathrm{~g}$ followed by $79.38 \mathrm{~g}$ for the fish diet and finally the rats fed the $62.89 \mathrm{~g}$ control diet.[20]Dally et al,(2010); [21]Beugré, (2008);[22] Trèches et al, (1994) also made similar observations with diets and on monogastric animals. These results confirm the importance of proteins in building the body. Physiologically, the weight gain observed with the RTCr diet * corroborates with the results obtained by [13] Adrian et al, (1991) with rats fed a reference diet and which indicates a regular development of cellular metabolism with effective synthesis clean matter from rats. This weight growth is influenced by the large amounts of total dry matter ingested and total protein ingested, in these rats, for the different diets studied. Furthermore, it is not enough for a food to contain a required level of protein, it must also be well digested and contain the various essential amino acids in balanced proportions [23] Aremu et al,(2006); [24] Taiwo et al, (2008); [25] Bouafou et al, (2007). Results of food consumption expressed in total ingested dry matter (MSTI) and total ingested protein (PTI) reveal that there is no significant difference between them $\mathrm{p} \geq 0.05$.

These results show that the rats appreciated the different diets formulated. As well as the coefficient of food efficiency and the coefficient of protein efficiency which show no significant difference between the rats fed on the different diets. The overall observation that emerges from all of the measurement parameters (MSTI, PTI, CEA, CEP) is that there is no significant difference between these values of nutritional parameters studied $\mathrm{p} \geq 0.05$.

The PTI values obtained are between 0.82 and $0.93 \mathrm{~g} / \mathrm{d}$. These results are similar to those obtained on Ivorian diets by [21] Beugré, (2008). In addition, other authors such as [26] Dally et al, (2014); [27]Onyeike and Achru , (2002) have clearly shown the advantage of the proteins administered to rats in front of protein-free diets. Indeed, [18]Azibuo et al, (2008); further suggested that the nutrients essential for the harmonious growth of organs are major proteins and minerals, including calcium and zinc. However, chemical analysis of this animal species clearly shows that it has more. This content is beyond the standards recommended by the [17]OMS, (1985); which gives a recommended value in proteins between (12-15\%) for a balanced meal. 
The appearance of the growth curves obtained from the average values materialize more precisely the physiological and weight states of the growing rats fed the different diets formulated in this study and we can deduce the qualitative aspect of this dish made from shrimp powder.

On a physiological level, the weight gain observed during such a diet could indicate a regular development of cell metabolism with synthesis of the body's own matter [28] Fouabi et al., (2017).

\section{Conclusion}

This nutritional study conducted in the Abidjan markets showed the presence of a good quantity of fresh or dried shrimp and especially the genus Penaeus notialis. Chemical analysis of the powder shows a high proportion of essential macronutrients. Proteins with $34.21 \%$ fat from $7.86 \%$. During animal experiments, the quantities of dry matter ingested and total protein ingested obviously affected the overall state of animal organisms fed by their weight gain. This animal species could constitute a favorable alternative in the substitution of our conventional proteins (meat and fish). Furthermore, more in-depth studies on the nature of the amino acid constituents of the constituent proteins can be studied, followed by hematological studies.

\section{Compliance with ethical standards}

\section{Acknowledgments}

Thanks to the authors and managers of the laboratories who contributed to the development of this research work as well as to the managers of the national nutrition program for their support during this study.

\section{Disclosure of conflict of interest}

There is no conflict of interest among the authors.

\section{References}

[1] FAO. (2012). Sustainable diets and biodiversity: directions and solutions for policy, research and action. Rome.

[2] IFPRI. (2016).Global Nutrition Report 2016: from promise to impact: ending malnutrition by 2030.Washington, DC.

[3] Svanberg SM, Nyman EMG, Anderson L and Nilson R. (1997). Effetcts of boiling and storage on diatary fiber and digestibility carbohydrates in various cultivar of carrots. J.Sci Food Agri, 73, 245-254.

[4] Shetty PS and MCPherson K. (1997). Diet, nutrition and chronicdisease. Lessons from contrastingworlds. Chichester: John Wiley et Sons, 301.

[5] Aristya AL, logoya AM and Albaomi AN. (2008). Total and total yaast and proteins profile of croat Milk Kelis with addition of sugar type and concentration. Pagan Gizi, 4(7), 39-48.

[6] Satmala P, Suraganamecakul V, Patanvee Wand Yashihashi T. (2017). Removal of soluble proteins during fermentation process for improving textural properties of traditional tai Rice noodle, Kamon-jean. Japan. Agri. Res. Quarterly, 51(4), 321-331.

[7] WHO. (2010). Nutrition Landscape Information System (NLIS) country profile indicators: interpretationguide. WHO Press, Geneva, Switzerland.

[8] FAO. (2003). Evolution of edible fats and evolution of their consumption. Tropical nutrition laboratory, ORSTOM center 34032. Montpellier cedex, France, 246-262.

[9] Hinard G. (1984). Food value of sea fish from edible marine crustaceans and molluscs. Chemist - Maritime Fisheries Council.

[10] AOAC. (1980). Official methods of analysis.15th Ed William.Horwihzedr Washington DC.

[11] AOAC. (1998). Officinal technology of analysis. Arlington, VA: Association of officinal analytique chemists, 16 (2), 23-34.

[12] Abu OMG and Eli NP. (2018). Effect of Smoke Drying on Proximate Composition and Some Heavy Metals in Shrimp and Oyster from Buguma Creek, Rivers State, Nigeria. Int J Poul Fish Sci., 2 (1), 1-5. 
[13] Adrian J., Rabache M., and Fragne R. (1991).Technique d'analyse nutritionnelle. Principe d'analyse. Ed. Lavoisier TEC.AND DOC. Paris: 451-478.

[14] Edah B. and Adeyemi Y. B. (2016). Comparative study on the nutritional composition of the pink shrimp (Penaeusnotialis) and tiger shrimp (Penaeus monodon) from Lagos lagoon, Southwest Nigeria

[15] Salvini S., Parpinel M., Gnagnarella P., Maisonneuve P., Turrini A. (1998). Bancadati di composizionedegli,alimenti per studiepidemiologici in Italia. Ed. Istituto Superiore di Oncologia.

[16] FAO. (2003). Evolution of edible fats and evolution of their consumption. Tropical nutrition laboratory, ORSTOM center 34032 Montpellier cedex, France: 246-262.

[17] OMS. (1985). Besoin énergétique et besoin en protéines, Rapports dune consultation conjointe d'expert Fao/OMS/ UNU, Série de rapports technique Genève (Suisse) 724. Tropicaux 10 rue Pierre Curie a Maison ALFORT publié par le ministère de la coopération ISNB $211084400 X 185$ p.

[18] Azibuo J. Y., Akromah R. A., Dapaah H. K., et Safo K. (2008). Evaluation of nutritional quality of groundnut Arachis hypogaeafrom Ghana.African Journal of Food Agriculture nutritional and Development.,8 (2): 1684-1694.

[19] Zannou T.V. (2005). Improvement strategies for high energy density cassava and soy flour by incorporating germ corn flour. Cocody University Doctoral Thesis. Cöte d'Ivoire 116P.

[20] Dally T., Meité A., Kouamé K.G., Kati-Coulibaly S. (2010). Nutritional efficiency of three Ivorian dishes: cabatoh with dah sauce; yam foutou with gouagouassou sauce; rice in seed sauce. Applied Biosciences Journal: 33: 20642090.

[21] Beugré G.A.M., (2008). Comparative study of the zootechnical performances and the organoleptic qualities of the varieties of local chicken of broiler and hybrids resulting from their genetic crossing. Doctoral thesis Univ. AboboAdjamé, Cöte d'Ivoire 130p.

[22] Trèches., AgborEgbe T., M’bome L. I., Mezoui M. C. (1994). Tests of adaptation of technological processes to the manufacture of dried products from yam cultivated in Cameroon (Discoreadumetorum and Drotundata). .Revue Sciences et Technique Science et santé Nutrition notebook., 6: 7-32.

[23] Aremu M. O., Olaofe.O.\& Akintayo T. E. (2006). A comparative study on the chemical and amino acid composition of some Nigerian under ultized legume flours PAK.Nurt.5, 34-38.

[24] Taiwo M., Tayor J.P., Events M.C., Kema M. (2008). First element of nutrition taken from the course given under the auspices of the FAO.TB Committee in Côte d'Ivoire.

[25] Bouafou K.G M., Kouame K.G., and Offoumou A.M. (2007). Nitrogen balance in the growing rat of dried maggots meal. Tropicultura. 25: 70-74.

[26] Dally T., A. Meité., K.G. Kouamé. \&S. Kati-Coulibaly. (2014). Nutritional quality of Ivorian food consumed: Biochicalseric studies on growing rats (wistar). Pakistan journal of nutrition. 13(5): 271-274.

[27] Onyeike E.N and Achru G.N. (2002). Chemical composition of selected Nigerian oil seeds and physicochemical propertiesof the oil extracts. Food chem.Journal. 77: 437-437.

[28] Fouabi F. G.; Meite A.; Dally T., Ouattara H. Kouamé K.G.G., and Kati-coulibaly S. (2017). Nuritional parameters of rats by the dried capillars Imbresia oyemensis's flour. International journal of food and nutritional Sciences. 6(1): 36-42.

\section{How to cite this article}

Dally T, Diby YB, Kahoubi GP, Kouamé B, Ouattara H, Méité A and Kati-Coulibaly S. (2020). Chemical analysis and nutritional study of shrimp powder (Penaeus notialis, Peneids, Decapods) from Côte d'Ivoire freshwater in rats (Rattus novegeus, Wistar). World Journal of Advanced Research and Reviews, 6(1), 82-88. 